are $\$ 3.00$ per year and should be addressed to American Folklore Society, the University of Texas Press, Box 7819, Austin, Texas, 78712. Abstracts of Folklore Studies is published for the American Folklore Society under the Editorship of Donald M. Winkleman, English Department, Bowling Green State University, to whom all correspondence and bibliographical notes should be sent. Those interested in abstracting journals relevant to African folklore should contact the Assistant Editor for Africa.

\title{
Sixth Pan-African Congress of Prehistory and Quaternary Study
}

THe Sixth Pan-African Congress of Prehistory and Quaternary Study will be held at Dakar from 2 to 8 December 1967 , under the auspices of the Presidency and the University of Dakar. The reunion at Dakar will coincide with the twentieth anniversary of the founding of the Congress at Nairobi, Kenya, in 1947. Information regarding the programme may be obtained from: Secrétariat du $\mathrm{VI}^{\circ}$ Congrès Panafricain de Préhistoire et de l'Étude du Quaternaire, I.F.A.N., B.P. 206, Dakar (Sénégal).

\section{Human Migrations in Southern Africa}

Wrrt reference to his article, "Evidence of Human Migrations from the Rock Art of Southern Rhodesia' (Africa, xxxv, 3, I965, pp. 263-85), Mr. C. K. Cooke has sent the following note from Mrs. Dora Fock of Kimberley:

The following observations may be of interest:

(1) You state: 'The worst area to be crossed is that from Etosha Pan southwards to the Brandberg Mountains.' I did this trip by car during 1963. From Okoukuejo westwards through the Kaokoveld there is plenty of grass for sheep even at the end of the dry season (September). There is, however, a little Mopani near Outjo but this can be avoided without undue deviation from the main route.

(2) In the Okambahe area the language spoken is Nama (Hottentot), the people living there are 'Klippkafiers' (Berg Damas). In the same area, not far from Uis, there were small tin workings. To extract the tin (crystal) from the crushed sand the miners employed elderly women who were called 'Schuttelweiber' (women shakers). By shaking a flat container these women were able to separate the heavy materials from the light and thus recover the tin. On questioning I learnt that in former times the Berg Dama used to obtain food from grass seeds which they collected and then separated-the seeds from the chaff and perhaps also sand-by this method. The seeds were ground into a flour and cooked as porridge. On further questioning I learnt that this art was no longer practised and therefore lost to the younger women because other food was now available. I am quite certain that in the remote past when your Hottentot shepherds migrated on the routes laid out by you in your paper they also increased their meagre food supplies by the use of grass seeds. So if there was grass for sheep there would be grass seeds for the shepherds.

I heard about the Schuttelweiber in $1954 / 5$ but as I only came to South West Africa in 1952 I did not realize that this method of separating materials was not well known.

It is understood that research is to be carried out on the Berg Dama people by an anthropologist from Mainz University. I hope that he will be able to investigate the 'Schuttelweiber' and publish his findings.

\section{East African Research Information Centre}

AN East African Research Information Centre is being established in Nairobi under the auspices of the East African Academy. The centre will compile and provide up-to-date information on past and current social research in the three East African countries Uganda, 